\title{
SPATIAL MODELLING OF MALARIA RISK FACTORS IN RUHUHA SECTOR IN THE EAST OF RWANDA
}

\author{
J. Tuyishimire' ${ }^{1}$ F. Kateera ${ }^{2}$, J. Mugisha ${ }^{1}$, S. Amer ${ }^{3}$, P. Mens ${ }^{2}$ \\ ${ }^{1}$ Center for Geographic Information Systems and Remote Systems-University of Rwanda (CGIS-UR) \\ ${ }^{2}$ University of Twente \\ ${ }^{3}$ KIT Amsterdam \\ Corresponding Author: Joseph Tuyishimire; tuyishimirejoseph@gmail.com
}

\begin{abstract}
Malaria is a vector borne disease posing a severe health risk to the population of Sub Saharan Africa and particularly in the East African Rift-Valley Region. The fact that malaria is still killing hundreds of thousands of people annually is due to insufficient researchers about its causing factors and the inefficiency of its control measures. With three main objectives: (1) to identify and map potential anopheles mosquito habitat, (2) to determine and map malaria prevalence, and, (3) to assess the relationship between malaria prevalence and malaria risk factors; the aim of this study is to spatially model malaria risk factors in a primarily rural area situated in South Eastern Rwanda. The data used in this research were obtained through a combination of high-resolution ortho-photography obtained from Rwanda Natural Resources Authority (RNRA) and primary data collection. In addition to this, detailed malaria occurrence and socio-economic data were obtained from Rwanda Biomedical Center (RBC). Spatial clusters of malaria occurrence were subsequently determined using Getis and Ord spatial statistics. This cluster analysis showed that malaria distribution is characterized by zones with high malaria risk, so called hot spots, zones with moderate malaria risk known as not significant spots and zones of low malaria risk known as cold spots. The current research demonstrates that malaria prevalence varies from one household to another and from one administrative unit (village) to another. The relationship between malaria prevalence and malaria risk factors was assessed using a logistic regression model. Results clearly indicate that malaria infection increases with the proximity to irrigated farmland. It also increases with household size. It was also proven that lower housing quality (mud houses; unburnt brick walls, earth floor) is associated with higher risk of malaria infection. This research proves that the proximity to irrigated farmland, the household size and housing quality are the main malaria underlying factors in the study area. It therefore suggests that people should not only live far from irrigated farmlands which are considered as the main anopheles mosquito breeding sites but also the housing quality should be improved.
\end{abstract}

Key words: Spatial modelling, Malaria risk, malaria causing factors, Ruhuha, Rwanda 


\section{RESUME}

Le paludisme est une maladie à transmission vectorielle qui pose un risque grave pour la santé à la population de l'Afrique sub-saharienne et en particulier dans la Vallée du Rift de l'Est. Le fait que le paludisme continue de tuer des centaines de milliers de personnes chaque année est due à des recherches insuffisantes sur ses facteurs de risque et l'inefficacité de mesures de contrôle. Avec trois objectifs principaux: (1) identifier et cartographier les habitats potentiels du vecteur, (2) déterminer et cartographier la prévalence du paludisme, et, (3) évaluer la relation entre la prévalence du paludisme et ses facteurs de risque; le but de cette étude est de mener une analyse spatiale des facteurs de risque du paludisme dans une zone essentiellement rurale située dans le Sud Est du Rwanda. Les données utilisées dans cette étude résultent d'une combinaison d'une orthophotographie obtenue du l'Office Rwandaise des Resources Naturelles (RNRA), et des visites de terrain. En plus de cela, le données sur le paludisme et la socio-économie ont été obtenues du Centre Biomedical du Rwanda (RBC). La distribution du paludisme a ensuite été déterminée à l'aide des statistiques spatiales Getis et Ord. Cette analyse de cluster a montré que la distribution du paludisme se caractérise par des zones présentant un risque élevé de paludisme, des zones à risque de paludisme modérée et les zones de faible risque de paludisme. La recherche actuelle démontre que la prévalence du paludisme varie d'un ménage à l'autre et d'une unité administrative (village) à une autre. La relation entre la prévalence du paludisme et les facteurs de risque de paludisme a été évaluée en utilisant un modèle de régression logistique. Les résultats indiquent clairement que l'infection du paludisme augmente avec la proximité de terres agricoles irriguées. Il augmente également avec la taille du ménage. Il a également été prouvé que la qualité inférieure du logement (maisons de boue, des murs de briques adobes, de la terre battue) est associée à un risque plus élevé d'infection du paludisme. Cette recherche prouve que la proximité de terres agricoles irriguées, la taille du ménage et la qualité du logement sont les principaux facteurs qui sous-tend le paludisme dans la zone d'étude. Il suggère donc que les gens ne devraient pas seulement vivre loin de terres agricoles irriguées qui sont considérés comme les principaux sites de reproduction de l'anophèle, mais aussi la qualité du logement devrait être améliorée. 


\section{I.INTRODUCTION}

Malaria is a mosquito-borne disease caused by protists of the genus Plasmodium falciparum which are introduced into the circulatory system by the bite from an infected female Anopheles mosquito (Smith et al., 2013). Human malaria is one of the most widespread endemic vector borne diseases throughout the tropical and subtropical regions of the World especially around the Equator (Ahmad et al., 2011).

Many studies about malaria were done in different parts of the World. Most of them investigated the ecology of the vector (Smith et al., 2013), efficiency of control measures (Karema et al., 2012) and spatial disease modelling (Hay et al., 2006). In Rwanda, studies about malaria mainly addressed malaria control policies and programmes. Thus, the focus was on the contribution of anti-malarial drugs, mosquito nets and residual sprays (Karema et al., 2006; NISR, 2012; President's Malaria Initiative, 2013), the prevalence of malaria in pregnant HIV positive women (Ivan et al., 2012) and the resistance of Plasmodium falciparum to antimalarial drugs (Karema et al., 2012). Most all the studies done in Rwanda have established a comprehensive malaria framework (causing factors, transmission and control measures), but they did not take into consideration geospatial factors that might affect malaria infection. This paper takes an explicitly geographical perspective by incorporating environmental factors and performing a geospatial analysis to identify environmental risk factors associated with malaria infection in Ruhuha.

The use of high resolution ortho-photography helped to identify potential anopheles vector breeding sites. Getis and Ord hot spots analysis was used as a geostatistical technique that can help in malaria clusters identification (Anamzui-Ya, 2012; Omumbo et al., 2005). The information gathered through the combination of GIS tools and spatial statistics analysis, allowed the spatial analysis of underlying factors of malaria infection and to show their relationship with malaria prevalence at small scale within the rural administrative Sector of Ruhuha.

\section{Malaria conceptual framework: transmission and prevalence}

Malaria conceptual framework used in this study consists of five components (Figure 1): (1) environmental variables which represent the main determinants for anopheles mosquito breeding sites (Machault et al., 2011; Nagasaki University, 2007); (2) the vector cycle (Stern et al., 2011; van Lishout, 2005), (4) the parasite cycle (Gahutu et al., 2011; Gascon et al., 1986); (4) demographic and socio-economic factors (J.-P. Bizimana et al., 2015; J. P. Bizimana et al., 2016) and; (5) vector control which consists of two methods. Natural control, which deals with environmental management and land use planning, and artificial control (use of insecticide treated nets and indoor residual sprays (Mboera et al., 2013; Mboera et al., 2014; Smith et al., 2013; Stratton, O'Neill, et al., 2008). 


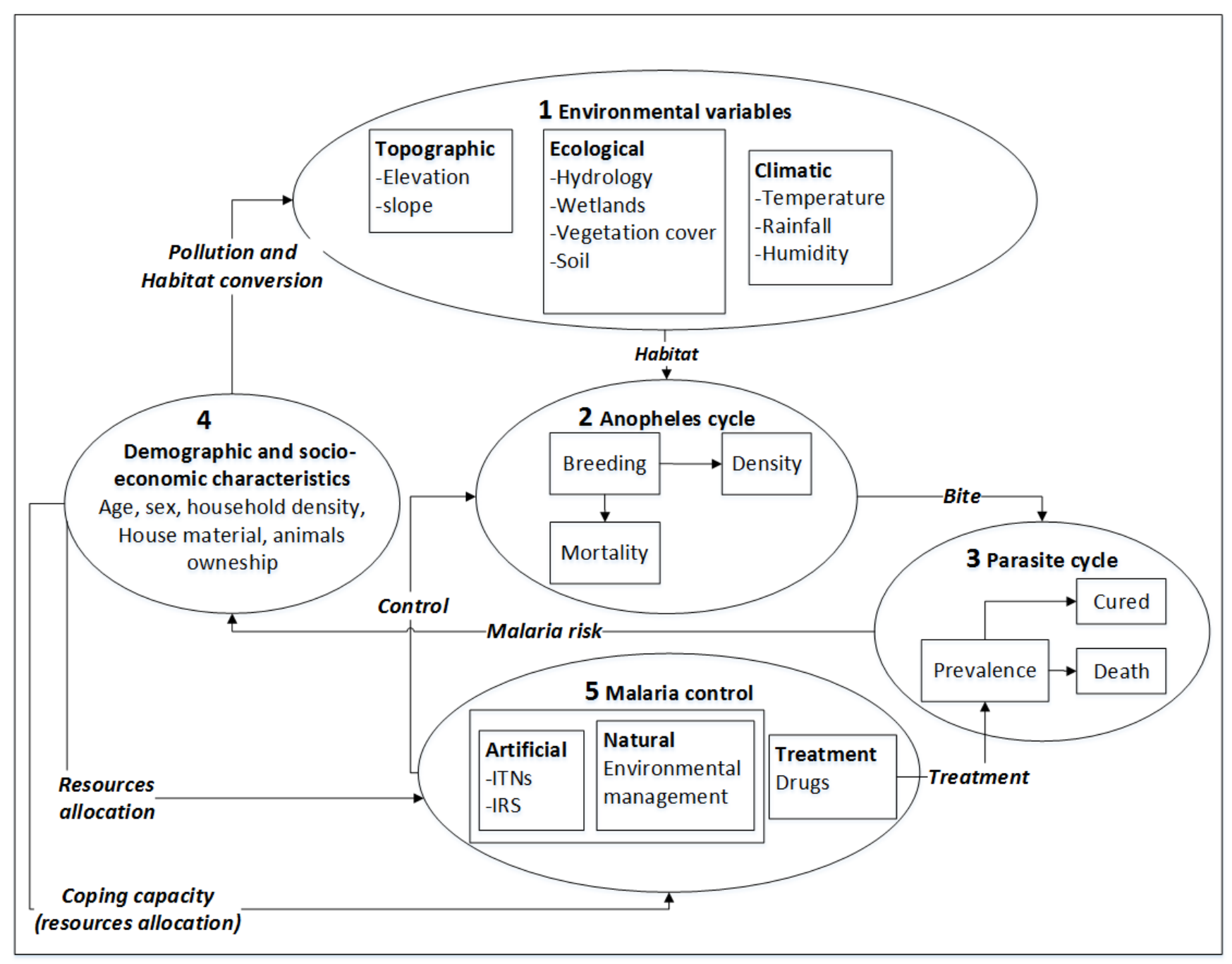

Figure 1.Conceptual framework

\section{II.MATERIALS AND METHODS}

\section{Study site}

This study was carried in Ruhuha Sector which is one of the 13 administrative sectors of Bugesera district in the Eastern Province of Rwanda. Ruhuha Sector consists of 5 administrative cells: Ruhuha, Gatanga, Bihari, Kindama and Gikundamvura (Figure 2). Together they cover an area of around 43 square kilometres. Ruhuha Sector is characterized by a succession of low plateaux, hills, dry valleys and swamps. The latter are mostly used for agricultural purposes or occupied by Papyrus Species and Cyperus species. (Especially near Cyohoha Lake). The micro-environment of these swampy areas represents a suitable habitat for anopheles mosquitos (Bugesera District, 2013).

Because of the environmental conditions of Ruhuha Sector and the Eastern Province of Rwanda in general, malaria represents a serious health threat (NISR, 2012). Malaria is the second cause of morbidity (23.3\%) in 
the area, after the sharp infections of the superior or lower respiratory ways which represent 27.3\% (Bugesera District, 2013). Its effect could have become higher unless control measures had been taken.

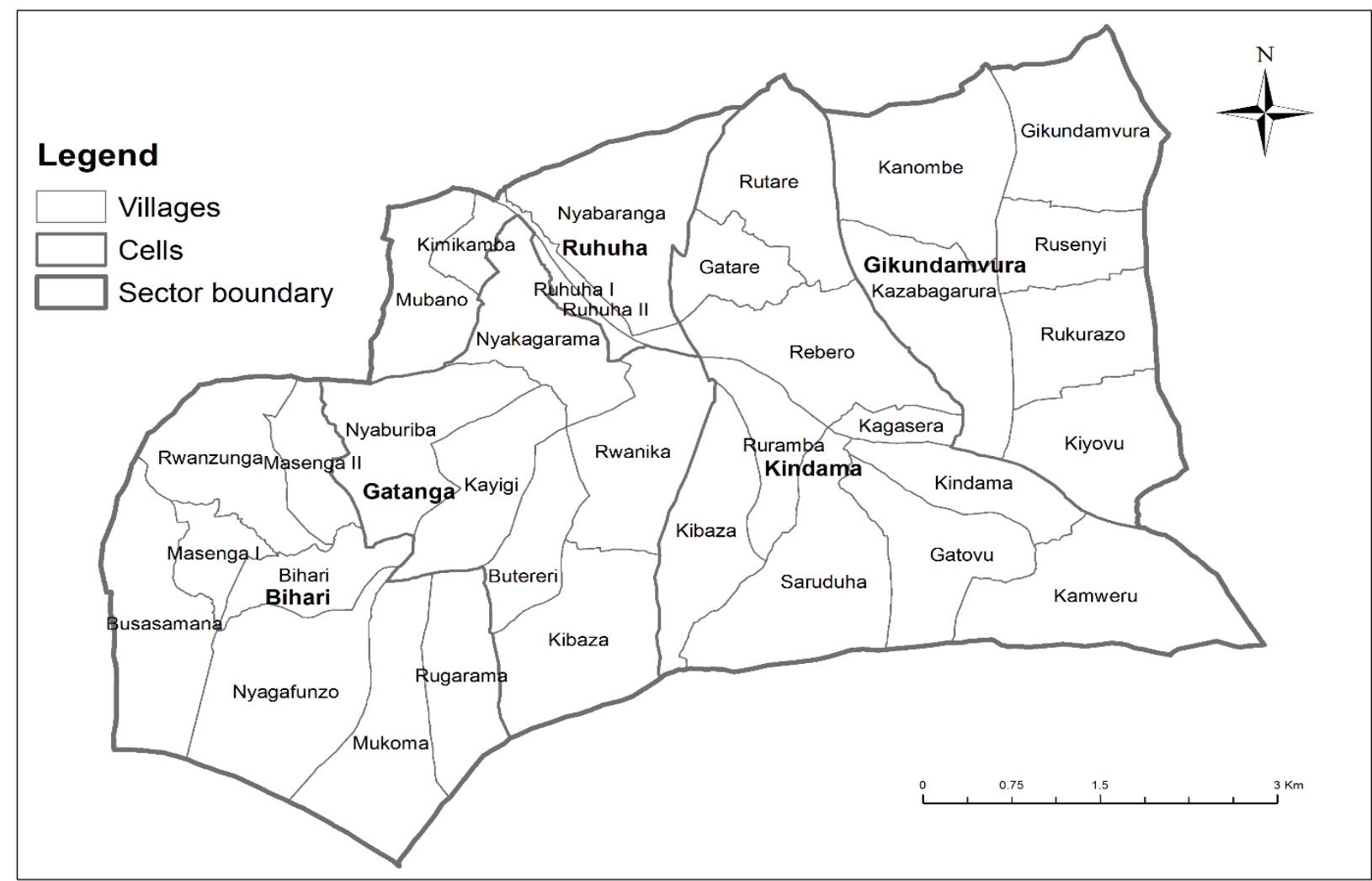

Figure 2. Study site

\section{Data}

\section{- Data collection}

This study is based on secondary data consisting of malaria infection, demographic and socio-economic data that were provided by the Rwanda Biomedical Center/Malaria Research program (RBC/MRC). The spatial data were provided by the National Institute of Statistics of Rwanda (NISR). Primary data identified anopheles mosquito breeding sites and land use types (Table 1) shows all the collected data.

\section{- Secondary data}

Secondary data were obtained from RBC/MRC in collaboration with the Royal Tropical Institute (KIT) through a research entitled "Empowering the Community towards Malaria Elimination". Another section of secondary data consisted of spatial information obtained from the NISR. These data consisted of demographic household size, age and gender), economic (animal ownership and household material), Malaria control measures (artificial and natural approaches and treatment), Malaria infection and spatial data (sector, cells and village boundaries and water sources).

The demographic, economic and malaria control measures data were directly recorded in tablets (Samsung 
Galaxy tabs). In addition, location (GPS coordinates) was recorded for each household. The collected data were then uploaded to the RBC / MRC server where they were combined from different villages and cleaned for further uses. 3443 households were surveyed.

Spatial data consisted of the shapefiles of the study area (sector, cells and village boundaries and water sources). They were all obtained from the National Institute of Statistics of Rwanda (NISR).

Table 1. Primary data used and their source

\begin{tabular}{|c|c|c|}
\hline Data & Specification & Source \\
\hline Ortho-photography & $\begin{array}{l}25 \mathrm{~cm} \text { resolution acquired in August } \\
2008 \text { and } 2009 \\
\text { Projection: ITRF-2005 }\end{array}$ & RNRA/DLM \\
\hline Study area shapefiles & $\begin{array}{l}\text { Rwanda baseline maps } 2010 \\
\text { Projection: ITRF-2005 }\end{array}$ & NISR \\
\hline Household XY coordinates & $\begin{array}{l}\text { GPS coordinates } \\
\text { Projection: WGS } 84\end{array}$ & $\mathrm{RBC} / \mathrm{MRC}$ \\
\hline Malaria infection data & $\begin{array}{l}\text { Number of people with Plasmodium } \\
\text { parasites per household }\end{array}$ & $\mathrm{RBC} / \mathrm{MRC}$ \\
\hline Number of people & Household level & $\mathrm{RBC} / \mathrm{MRC}$ \\
\hline Population density & Cell and village levels & NISR \\
\hline $\begin{array}{l}\text { Age and sex of the } \\
\text { population of study }\end{array}$ & Individual based & $\mathrm{RBC} / \mathrm{MRC}$ \\
\hline Animal ownership & Presence of animals in the household & $\mathrm{RBC} / \mathrm{MRC}$ \\
\hline House material & $\begin{array}{l}\text { The material that makes the roof, walls } \\
\text { and the floor }\end{array}$ & $\mathrm{RBC} / \mathrm{MRC}$ \\
\hline Use of control measures & $\begin{array}{l}\text { Number of ITNs per Household, sprays, } \\
\text { cutting bushes, clearing stagnant water } \\
\text { and others }\end{array}$ & $\mathrm{RBC} / \mathrm{MRC}$ \\
\hline $\begin{array}{l}\text { Anopheles micro-habitat in } \\
\text { Ruhuha }\end{array}$ & $\begin{array}{l}\text { GPS coordinates and elevation of } \\
\text { Anopheles breeding sites } \\
\text { Projection: WGS } 84\end{array}$ & Field work \\
\hline Land use of the study area & $\begin{array}{l}\text { Training point for accuracy assessment } \\
\text { Projection: WGS } 84\end{array}$ & Field work \\
\hline
\end{tabular}

\section{- Primary data}

Primary data consisted of potential malaria breeding sites (irrigated farmland and water reservoir), land use and local people's view about malaria causing factors and transmission. With the guidance of administrative cells Community Health Workers (CHWs), the coordinates and the elevation of each breeding site were marked using a hand-held Global Positioning System (GPS), GARMIN etrex 12 CHANNEL (Lizzi et al., 2014) and the land use type identified on each breeding site was described The captured data were later 
imported via map source 6.16.3 Software and processed in ArcGIS 10.2 package.

\section{Data analysis}

\section{- Data integration}

The data from RBC consisted of laboratory results that were stored in laboratory notebook and in RBC/MRC general register and demographic, economic and malaria control measures that were stored on the online RBC/MRC server. A link code was created so that data from the three sources could be integrated into ArcGIS Software. The same code was used to link data from the field, RBC and NISR. For Compatibility purpose, spatial data consisting of the location of the surveyed households obtained from RBC which were in decimal degrees and the data collected from the field which were in WGS 84 were converted in ITRF-2005 in order to avoid spatial shifts from boundary data obtained from NISR. This operation was performed in ArcGIS using "Project" tool (Anamzui-Ya, 2012; Omumbo et al., 2005; Zayeri et al., 2011).

\section{- Steps for data analysis}

\section{a. Potential anopheles mosquito habitat mapping}

The land use was delineated from an ortho-photography of the study area through a visual image interpretation (Anamzui-Ya, 2012) as shown on Figure 5. Through the use of validation points collected from the field, A confusion matrix was generated in ArcGIS to assess the accuracy of the produced land use map as shown in Table 2 (Bates et al., 2004). Potential anopheles mosquito habitat map was created through the integration of the information extracted from the land use map and field observations (Figure 6).

Table 2. Land use accuracy assessment table

\begin{tabular}{lcccccc}
\hline Classes & Settlement & $\begin{array}{l}\text { Forest } \\
\text { plantation }\end{array}$ & $\begin{array}{l}\text { Closed } \\
\text { agriculture }\end{array}$ & Irrigation & $\begin{array}{l}\text { Open } \\
\text { agriculture }\end{array}$ & Accuracy (\%) \\
\hline Settlement & 18 & 0 & 1 & 0 & 0 & 95 \\
Forest plantation & 0 & 8 & 1 & 1 & 0 & 80 \\
Closed agriculture & 0 & 0 & 10 & 0 & 1 & 91 \\
Irrigation & 0 & 0 & 0 & 4 & 0 & 100 \\
Open agriculture & 1 & 0 & 0 & 0 & 10 & 91 \\
\hline Overall accuracy $(\%)$ & & & & & & 91 \\
\hline Kappa (\%) & &
\end{tabular}

\section{b. Malaria prevalence and clustering}

Malaria prevalence (ratio of infected people over the total population) was analysed at village level. Getis and Ord (G*) index (Getis \& Ord, 1996; Getis \& Ord., 1995; Ord \& Getis., 2001; Sutherst, 2004) was used to test the significance of malaria clusters within the surveyed households. 


\section{c. Factors of malaria infection}

Malaria causing factors in the study area were determined from the literature and interviews with the local Community Health Works (CHWs) and the RBC/MRC staff in charge of malaria control. They were categorized in three groups: environmental, demographic and economic (Malaria conceptual framework in Figure 1). The identified malaria causing factors were either nominal or ratio. Nominal data consisted of land use and housing quality. Ratio data consisted of the altitude, household size and the distance to Anopheles breeding sites. To know the distance from each of the observed households to the nearest vector breeding, distance maps were created in ArcGIS using Euclidian distance tool. The same maps served as inputs during the extraction of distance variables.

\section{d. Relationship between malaria infection and malaria causing factors}

The potential relevant variables for malaria prediction were screened through the process of multicollinearity analysis (Correlation coefficients and VIFs calculation). In statistical modelling, it is important to avoid the inclusion of related variables which can reflect the same reality leading to the issue of information duplicate. After viewing the correlation matrix, there were weak correlations between the altitude and the distance to marshlands $(r=0.57)$, between the distance to water reservoir and the distance to Health Center $(r=0.53)$ and cutting bush and removing stagnant water $(\mathrm{r}=0.68)$. So VIF was used as the next step to test collinearity. All the variables had VIFs $<10$ (see Table 3 ) and therefore, collinearity was not a problem. The screened variables were then inputted in a stepwise logistic regression model. In fact, the stepwise regression model has the advantage of showing the model improvement as new predictors are added (Tabachnick \& Fidell, 2001) .

Table 3.Screening of Independent variables

\begin{tabular}{llllll}
\hline Variable & $R^{2}$ & $V I F$ & Variable & $R^{2}$ & $V I F$ \\
\hline Altitude & 0.44 & 1.79 & Household size & 0.29 & 1.41 \\
Distance to marshland & 0.54 & 2.17 & High quality housing & 0.51 & 2.04 \\
Distance to water reservoir & 0.61 & 2.56 & Low quality housing & 0.27 & 1.37 \\
Distance to household & 0.34 & 1.52 & Animal ownership & 0.32 & 1.47 \\
Forest & 0.07 & 1.08 & Distance to Health Center & 0.66 & 2.94 \\
Closed agriculture & 0.06 & 1.06 & Cutting bushes & 0.68 & 3.13 \\
Open agriculture & 0.13 & 1.15 & Remove stagnant water & 0.69 & 3.16 \\
\hline
\end{tabular}

\section{e. Regression model}

The logistic regression model was chosen for this study because it has the capacity predicting categorical variables by nominal and ratio variables at the same time. The stepwise logistic regression model was used for testing the relationship between malaria infection (Presence of parasites in the blood $=1$, absence $=0$ ) and its causing factors and control measures. In fact, the stepwise regression helps to detect the model 
improvement if new predictors are added and is better for logistic regression with dummy variables (Dunn et al., 2011). Odds ratio (OR and Wald were used to test the significance of the predicted coefficients (Field et al., 2012)

\section{III.RESULTS AND DISCUSSION}

\section{Malaria prevalence}

Compared to the country statistics (1.2\%) as described by Stratton, O'Neill, et al. (2008), the study area was characterized by a high malaria prevalence (3.2\% as shown in Table 4). A large number of households were characterized by one infected individual. Malaria was differently distributed in the study area with the highest prevalence in Gikundamvura Cell (Figure 3). According to local health officers and CHWs, the higher malaria prevalence in Gikundamvura cell could be justified by the fact that a large proportion of people in Gikundamvura are far from Ruhuha Health Center and have houses of low quality. In fact, people who live far from the health center have difficulties to access malaria treatment and, the infected people serve as the parasite reservoirs (Ngom \& Siegmund, 2010; Smith et al., 2013).

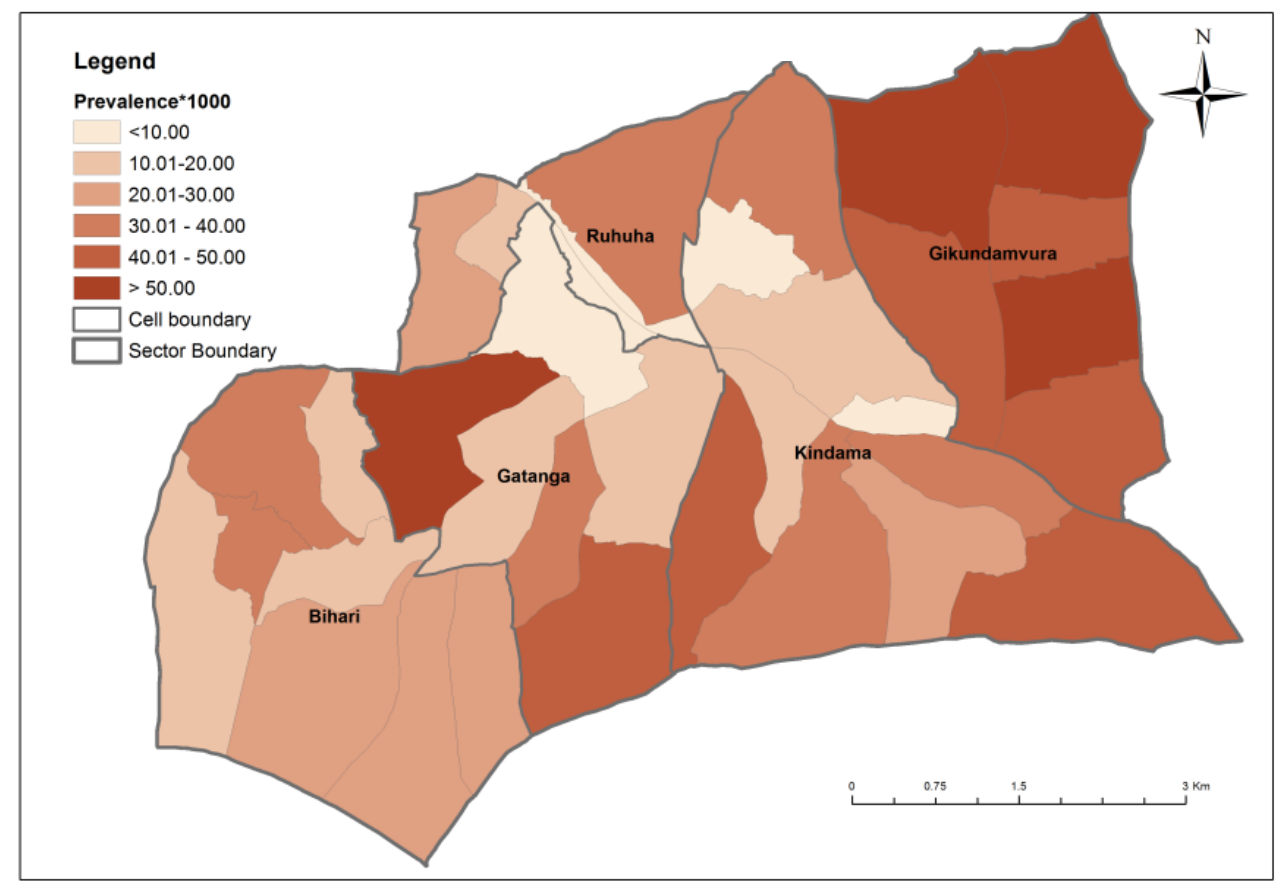

Figure 3. Malaria prevalence per village

Malaria prevalence at village level is heterogeneously distributed as well (Figure 3). Most of the villages in the study area are characterized by a high malaria prevalence compared to the national statistics. Gikundamvura, Rukurazo, Kanombe, and Kazabagarura of Gikundamvura Cell; Nyaburiba of Gatanga Cell; and Kamweru of Kindama Cell, Rwanzunga of Bihari Cell and Mubano of Ruhuha Cell are characterized by higher malaria prevalence (> 5\%). Compared 
to the WHO (2008) report suggesting that areas characterized by more than one malaria case per thousand people are at high risk, all the villages of the study area are at high risk of malaria.

Table 4. Malaria Prevalence per cell

\begin{tabular}{lcccccc}
\hline Cell & Area_sqkm & $\begin{array}{c}\text { Number of } \\
\text { households }\end{array}$ & Population & $\begin{array}{l}\text { Population } \\
\text { density }\end{array}$ & $\begin{array}{l}\text { Infected } \\
\text { people }\end{array}$ & Prevalence*1000 \\
\hline Bihari & 9.86 & 871 & 4160 & 422 & 90 & 22 \\
Gatanga & 8.14 & 827 & 3977 & 489 & 143 & 36 \\
Kindama & 12.63 & 1291 & 6512 & 516 & 165 & 25 \\
Ruhuha & 3.76 & 825 & 4087 & 1086 & 58 & 14 \\
Gikundamvura & 8.73 & 780 & 3195 & 366 & 198 & 62 \\
Overall & 43.12 & 4594 & 21931 & 509 & 654 & 32 \\
\hline
\end{tabular}

\section{Malaria clustering}

The biggest number of hot spots was observed in Gikundamvura cell. Ruhuha was the cell with less malaria

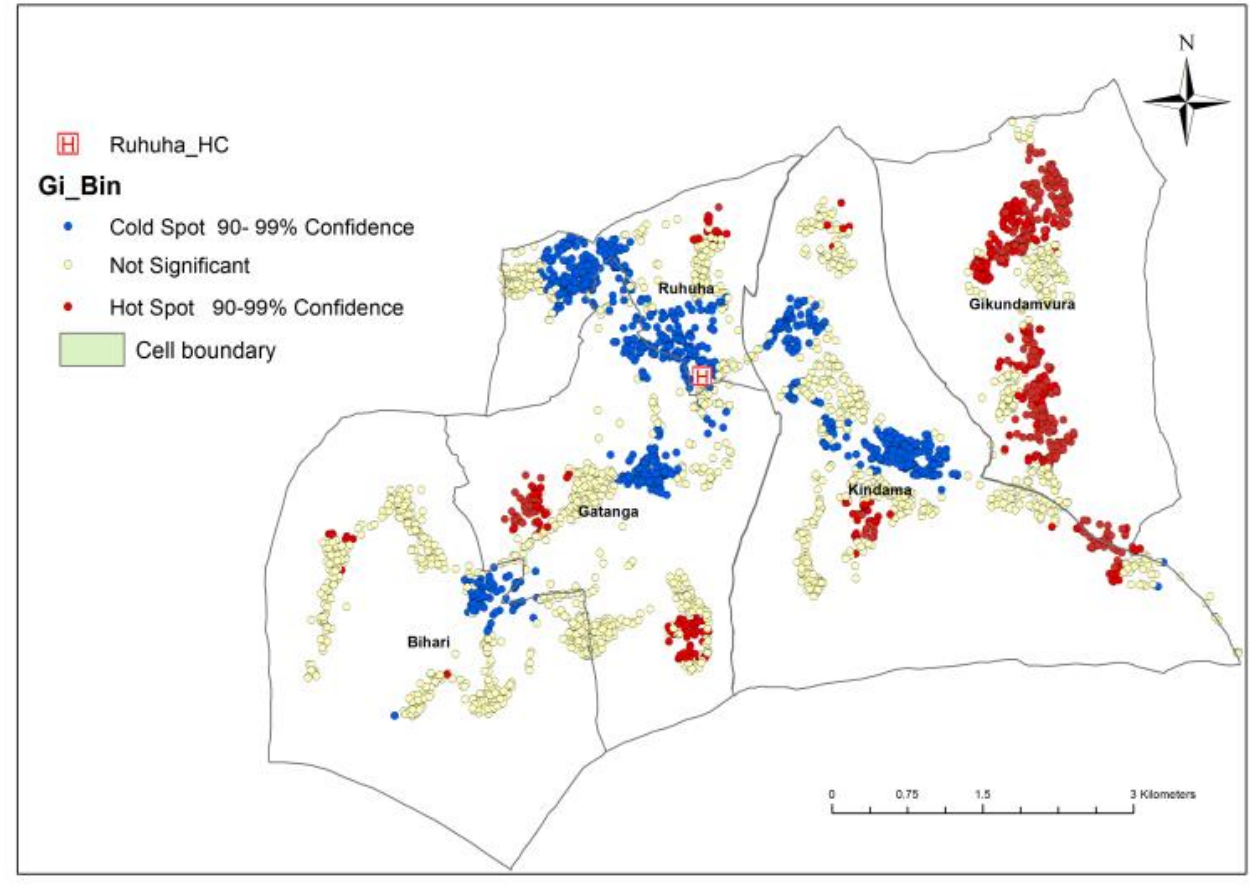

Figure 4. Malaria clustering in Ruhuha Sector cases (Figure 4). The probability of getting malaria is higher (Zone characterized by a high prevalence) near the place where the observed prevalence was higher too. This distribution map is realistic given the fact that humans are at the same time hosts and reservoirs of Plasmodium $\quad S p . \quad$ In accordance with Githeko et al. (2012), malaria distribution in the study area is also justified

by the principle of spatial autocorrelation by which neighboring people share the same characteristics such as malaria causing factors and prevention measures and are therefore under the same risk, unless different intervention measures are relied upon.

\section{Land use of the study area}

The land use of the study area was classified in six classes: Open agriculture consisting mainly of perennial crops, closed agriculture made of banana and coffee plantations, forest made mostly of eucalyptus plantations, lake, settlement and irrigated farmland where the predominant crop was rice (Figure 5). 
The overall accuracy and the kappa $\left(\mathrm{K}^{*}\right)$ value were calculated. In accordance with Bates et al. (2004), the accuracy assessment proved a strong agreement $\left(\mathrm{K}^{*}=90 \%\right.$, overall accuracy $\left.=91 \%\right)$ as shown in Table 2 and

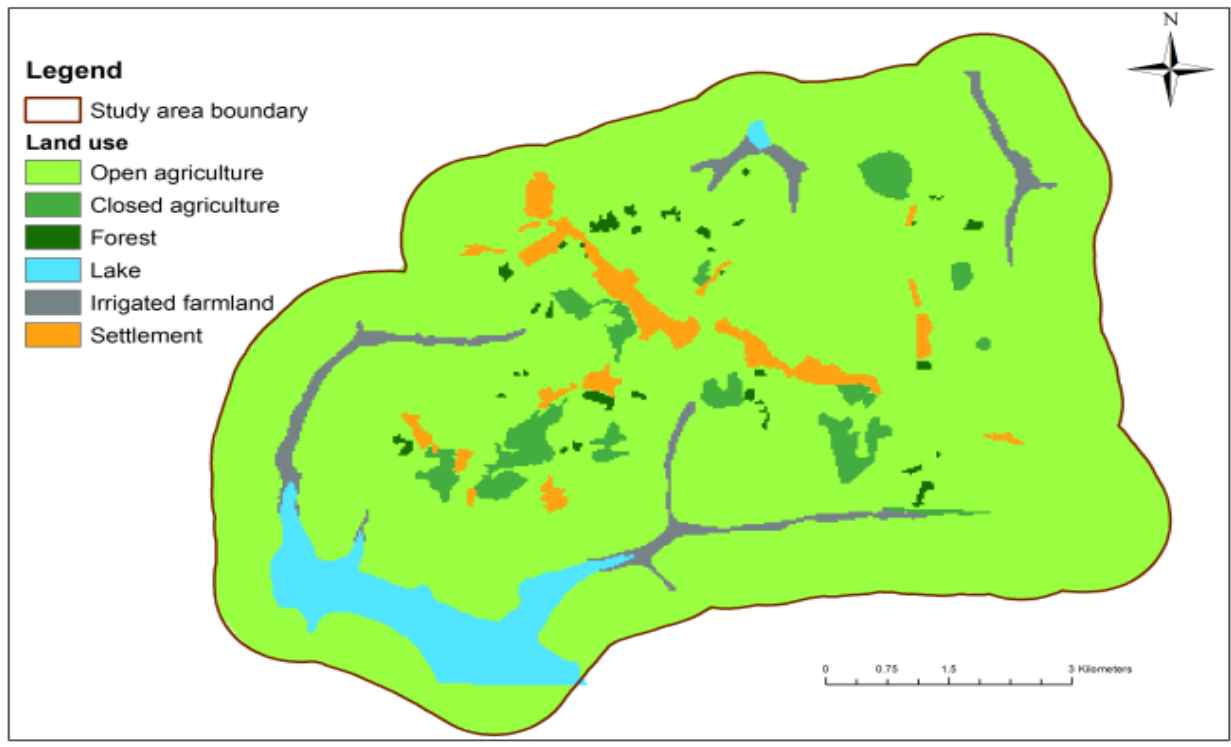

\section{breeding sites}

Potential anopheles mosquito habitats in the study area consist of irrigated farmlands, water reservoirs, closed agriculture, forest plantation and the lake (See Figure 6).

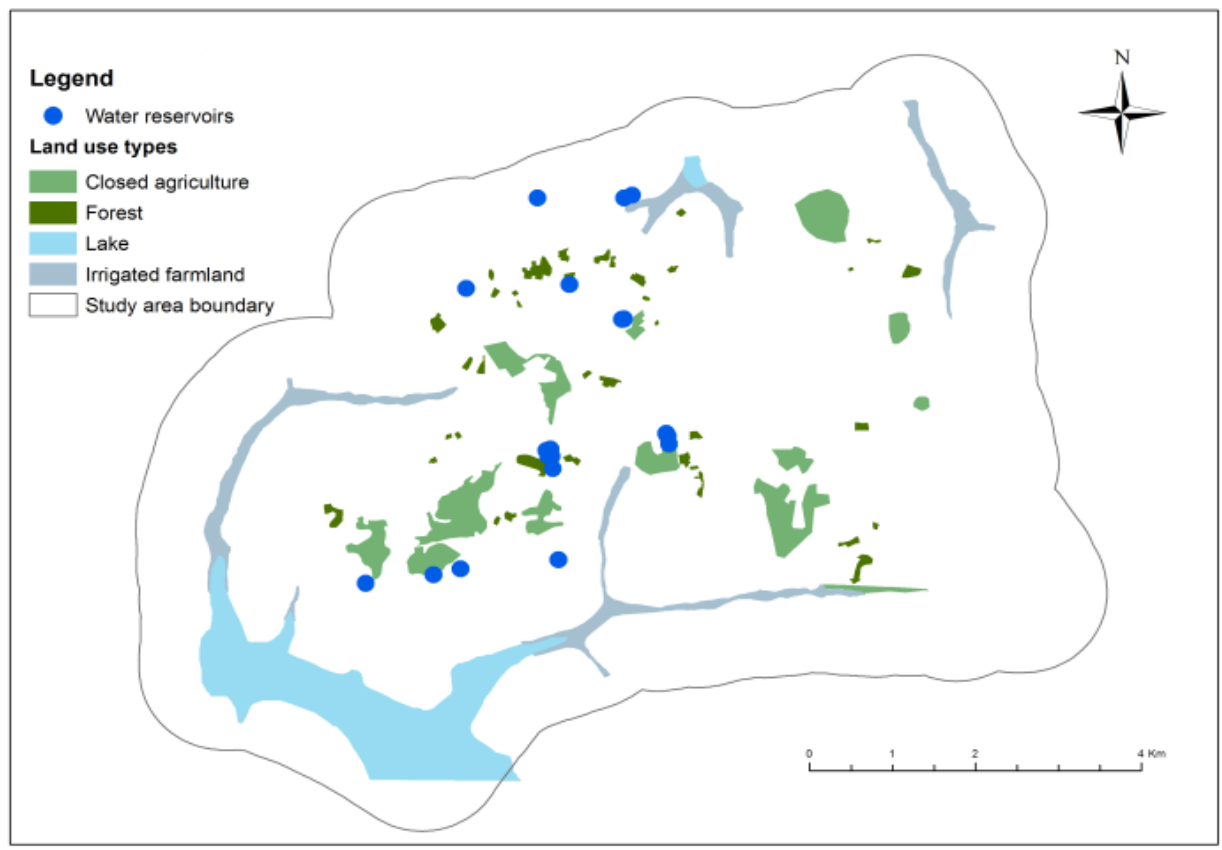

Figure 6. Potential anopheles mosquito breeding sites.

Irrigated farmlands and water reservoirs are places where ecological conditions are favourable for adult mosquito breeding and larvae survival. This was confirmed by Wielgosz et al. (2012) in East Africa and Morgan (2001) in Burkina Faso. In accordance with the findings of Protopopoff et al. (2009) in Accra and 
Munga et al. (2006) in the Western Kenya, irrigated farmlands and water reservoirs were considered as breeding sites and habitats at the same time because mosquitoes could stay there before their migration for blood meal search. The intermediate habitats (forest plantations, closed agriculture and vegetation on the lake shore) may serve as resting sites during the mosquito flights.

\section{Relationship between malaria infection and underlying factors}

To investigate the best predictors of malaria infection, we used a stepwise logistic regression where the Wald statistics and the OR proved their significance (Table 4). The logistic regression model, showed a low predictive power $\left(\mathrm{R}^{2}=13 \%\right)$. This is explained by the fact that malaria infection is a result of many factors (Stratton, O'Neill, et al., 2008) and therefore, the chosen variables were not the only malaria underlying factors in the study area. According to local CHWs and RBC/MRC staff in charge of malaria control, lower level of education and the habit to use mosquito nets could be ones of the causes underlying malaria prevalence though they were not assessed in this study.

\section{- Demographic variables and Malaria infection}

Malaria infection increases with the household size (Wald=77.3 and OR $>1$ ). The increase of malaria with household size is realistic in the study area because if a household contains many individuals, when one of them is infected, he could serve as a reservoir for other (Mboera et al., 2014; Nagasaki University, 2007; Ngom \& Siegmund, 2010). In general, more people in the study area are low income population and large families with bad quality houses and are therefore prone to malaria (Githeko et al., 2012; Nagasaki University, 2007).

In conformity with the results of this study, the high household size was also suggested among malaria underlying causes in the fringe zones of East African Cities by Mboera et al. (2013). . The association between malaria infection and the household size was also found by WHO (2008) in the annual malaria report while in their review on the persistence of malaria problem, Stratton, O'Neill, et al. (2008) mentioned the poverty and increasing population as associated problems which are among the main causes of malaria in developing countries. The same authors suggest that the improvement of economic conditions and small household size could be the best ways to control malaria spread in developing countries.

\section{- Economic variables and Malaria infection}

House materials are the only economic malaria predictors (Table 4). Compared to houses with medium quality walls (reference category during the process of dummy coding), the infection is lower in houses made of high quality wall materials (burnt bricks and cement blocks) (Wald=5.7, OR<1) and higher in houses with low quality walls (Wald=39.9, OR>1). Malaria infection is lower in houses made of cement floor (Wald=31.3, 
OR<1) compared to those with earth floor (reference category).

Few houses of good quality made especially of burnt bricks or cement blocks for walls and tiles or iron sheets for roofs, have tight doors and windows so that mosquito could not enter easily except when doors or windows are open. Conversely, most of houses in the study area are made of medium quality (unburnt bricks) walls which in most of cases have windows and doors that are not tight enough to block the mosquito entrance. In addition, a large proportion of houses with low quality (mud) walls were also proved positively associated with malaria infection. The quality of mud wall houses is the worst and they favour an easy contact between the mosquito and humans.

Table 4. Relationship between malaria prevalence and causing factors

\begin{tabular}{|c|c|c|c|c|c|c|c|c|}
\hline \multirow[t]{2}{*}{ Variable } & \multirow[t]{2}{*}{$B$} & \multirow[t]{2}{*}{ S.E. } & \multirow[t]{2}{*}{ Wald } & \multirow[t]{2}{*}{$d f$} & \multirow[t]{2}{*}{$P$-value } & \multirow[t]{2}{*}{$O R$} & \multicolumn{2}{|c|}{ 95\% C. I. for $O R$} \\
\hline & & & & & & & Lower & Upper \\
\hline Distance to marshland & -1.005 & .235 & 18.238 & 1 & .000 & .366 & .231 & .580 \\
\hline $\begin{array}{l}\text { Distance to household } \\
\text { with at least one infected } \\
\text { people }\end{array}$ & .463 & .110 & 17.825 & 1 & .000 & 1.589 & 1.282 & 1.970 \\
\hline Household size & .253 & .029 & 77.368 & 1 & .000 & 1.288 & 1.217 & 1.363 \\
\hline High housing quality & -1.487 & 618 & 5.788 & 1 & .016 & .226 & .067 & .759 \\
\hline Low housing quality & .782 & .124 & 39.968 & 1 & .000 & 2.186 & 1.716 & 2.786 \\
\hline $\begin{array}{l}\text { High housing quality } \\
\text { (Cement) }\end{array}$ & -.942 & .200 & 22.243 & 1 & .000 & .390 & .264 & .577 \\
\hline Distance to Health Centre & -1.013 & .174 & 33.918 & 1 & .000 & .363 & .258 & .511 \\
\hline Constant & -2.591 & .339 & 58.499 & 1 & .000 & .075 & & \\
\hline
\end{tabular}

The relationship between poor housing quality and malaria infection that was found in this study is in confirmation with Stratton, O'Neill, et al. (2008) in their review on the persistent problem of malaria. The same relationship is in contradiction with the results of Morgan (2001) which suggested a lack of relationship between malaria prevalence and house material in the semi-urban areas of Burkina Faso. This contradiction could be attributed to differences in housing conditions between Semi-urban areas of Burkina Faso and those in the Eastern Africa. 
Distance to marshlands is negatively related to malaria infection (Wald=18.2 and $\mathrm{OR}<1$ ). People living near irrigated farmlands are more exposed to malaria infection because mosquito can fly and reach them very easily and the higher the distance, the less the exposure. Similarly, in their study in the Western highlands of Kenya, Munga et al. (2006) found that people living near irrigated farmlands were more affected compared to those living far away. In their study in Accra, Protopopoff et al. (2009) suggested that people should live at least beyond $1000 \mathrm{~m}$ (maximum anopheles flight distance) from irrigated farmlands and the further away the better.

\section{IV.CONCLUSIONS}

This research showed that Malaria prevalence (number of infected people/the whole population) is higher in the study area compared to the country statistics and is differently distributed in the surveyed villages and cells. Malaria decreases with the distance from irrigated farmland. Houses with earth floors are characterized by a higher malaria infection compared to those with cement floors. Malaria infection is higher in low quality (mud) walls and lower in high quality (burnt bricks and cement blocks) walls.

Malaria is a results of many factors that the identification, the collection and the inputs of all the needed variables is not an easy task. The inputs of this model are not exhaustive and as result, it showed a low performance. The inclusion of other variables such as the level of education, the habit to use bed nets and anopheles entomological data could improve the model performance.

The current study recommends that in order to minimize reservoir-host contact, not only the quality of houses should be improved, but also people should live far from anopheles breeding sites and preferably beyond its maximum flight distance.

\section{V.REFERENCES}

Ahmad, R., Ali, W., Nor, Z., Ismail, Z., Hadi, A., Ibrahim, M., \& Lim, L. (2011). Mapping of mosquito breeding sites in malaria endemic areas in Pos Lenjang, Kuala Lipis, Pahang, Malaysia. Malaria Journal, 10(1), 361.

Anamzui-Ya, J. A. (2012). Spatial analysis and mapping of cholera causing factors in Kumasi, Ghana. Enschede: MSc Thesis.University of Twente, Faculty of Geo-Information and Earth Observation (ITC).

Bates, I., Fenton, C., Gruber, J., Lalloo, D., Medina, L. A., \& Squire, S. B. (2004). Vulnerability to malaria, tuberculosis, and HIV/AIDS infection and disease. Part I: determinants operating at individual and household level. Lancet Infect Dis, 4.

Bizimana, J.-P., Twarabamenye, E., \& Kienberger, S. (2015). Assessing the social vulnerability to malaria in Rwanda. Malaria Journal, 14(1), 2. doi: 10.1186/1475-2875-14-2 
Bizimana, J. P., Kienberger, S., Hagenlocher, M., \& Twarabamenye, E. (2016). Modelling homogeneous regions of social vulnerability to malaria in Rwanda. Geospatial Health, 11.

Bugesera District. (2013). Bugesera District. Retrieved 29/07, 2013, from http://www.bugesera.gov.rw/

Dunn, C. E., Le Mare, A., \& Makungu, C. (2011). Malaria risk behaviours, socio-cultural practices and rural livelihoods in southern Tanzania: implications for bed net usage. Soc Sci Med, 72.

Field, C. B., Barros, V., Stocker, T. F., Qin, D., Dokken, D. J., \& Ebi, K. L. (2012). Managing the risks of extreme events and disasters to advance climate change adaptation. Cambridge Melbourne, Madrid, Cape Town, Singapore, São Paulo, Delhi, Tokyo, Mexico City, New York: Special Report of the Intergovernmental Panel on Climate Change; Cambridge University Press.

Gahutu, J. B., Steiniger, C., Shyirambere, C., Zeile, I., Cwinya-Ay, N., Danquah, I., . . Mockenhaupt, F. P. (2011). Prevalence and risk factors of malaria among children in southern highland Rwanda. Malar J, 10. doi: 10.1186/1475-2875-10-134

Gascon, J., Pluymaekakrs, J., \& Bada, J. L. (1986). Chloroquine-resistant falciparum malaria from Rwanda. Transactions of the Royal Society of Tropical Medicine and Hygiene, 80(2), 351.

Getis, A., \& Ord, J. K. (1996). Local spatial statistics: On overview. In Spatial Analysis : Modelling in GIS Environment New York John Wiley \& Sons Inc.

Getis, A., \& Ord., J. K. (1995). Local spatial autocorrelation statistics: distributional issues and an application. Geographical Analysis 27, 286-306.

Githeko, A. K., Ototo, E. N., \& Guiyun, Y. (2012). Progress towards understanding the ecology and epidemiology of malaria in the western Kenya highlands: opportunities and challenges for control under climate change risk. Acta Trop, 121.

Hay, S. I., Graham, A. J., \& Rogers, D. J. (2006). Global Mapping of Infectious Diseases-Methods, Examples and Emerging Applications. Oxford,UK: Academic Press.

Ivan, E., Crowther, N. J., Rucogoza, A. T., Osuwat, L. O., Munyazesa, E., Mutimura, E., . . Grobusch, M. P. (2012). Malaria and helminthic co-infection among HIV-positive pregnant women: Prevalence and effects of antiretroviral therapy. Acta Tropica, 124(3), 179-184. doi: http://dx.doi.org/10.1016/j.actatropica.2012.08.004

Karema, C., Aregawi, M., Rukundo, A., Kabayiza, A., Mulindahabi, M., Fall, I., . . Binagwaho, A. (2012). Trends in malaria cases, hospital admissions and deaths following scale-up of anti-malarial interventions, 2000-2010, Rwanda. Malaria Journal, 11(1), 236.

Karema, C., Fanello, C. I., Van Overmeir, C., Van geertruyden, J.-P., van Doren, W., Ngamije, D., \& D’Alessandro, U. (2006). Safety and efficacy of dihydroartemisinin/piperaquine (Artekin $\left.{ }^{\circledR}\right)$ for the treatment of uncomplicated Plasmodium falciparum malaria in Rwandan children. Transactions of the 
http://dx.doi.org/10.4314/rj.v1i1S.10D

Royal Society of Tropical Medicine and Hygiene, 100(12), 1105-1111. doi: http://dx.doi.org/10.1016/j.trstmh.2006.01.001

Lizzi, K. M., Qualls, W. A., Brown, S. C., \& Beier, J. C. (2014). Expanding integrated vector management to promote healthy environments. Trends Parasitol, 30.

Machault, V., Vignolles, C., Borchi, F., Vounatsou, P., Pages, F., Briolant, S., . . Rogier, C. (2011). The use of remotely sensed environmental data in the study of

malaria. Geospatial Health, 5(2), 151-168.

Mboera, L. E. G., Mazigo, H. D., Rumisha, S. F., \& Kramer, R. A. (2013). Towards malaria elimination and its implication for vector control, disease management and livelihoods in Tanzania. Malaria World Journal, 4.

Mboera, L. E. G., Mukabana, W. R., Njunwa, K. J., \& Kabbale, F. G. (2014). Integrated research partnerships for malaria control through an ecohealth approach in East Africa: Kenya. Rwanda: Tanzania and Uganda Projects. Final Report.

Morgan, L. (2001). Community participation in health: perpetual allures, persistent challenge. Health Policy Plan, 16.

Munga, S., Noboru, M., Guofa, Z., Emmanue, 1. M., Okeyo-owuor, J. B., Andrew K., G., \& Yan, G. (2006). Association between Land Cover and Habitat Productivity of Malaria Vectors in Western Kenyan Highlands. American Journal of Tropical Medicine and Hygiene, 74(1), 69-75.

Nagasaki University. (2007). Spatial Relationship between Adult Malaria Vector Abundance and Environmental Factors in Western Kenya Highlands. from http://naosite.lb.nagasakiu.ac.jp/dspace/handle/10069/19218

Ngom, R., \& Siegmund, A. (2010). Urban malaria in Africa: an environmental and socio-economic modelling approach for Yaoundé, Cameroon. Natural Hazards, 55(3), 599-619. doi: 10.1007/s11069-009-9485$\mathrm{X}$

NISR. (2012). Rwanda Demographic and Health Survey 2010 (pp. 411). Kigali, Rwanda.

Omumbo, J. A., Hay, S. I., Snow, R. W., Tatem, A. J., \& Rogers, D. J. (2005). Modelling malaria risk in East Africa at high-spatial resolution. Trop Med Int Health, 10. doi: 10.1111/j.1365-3156.2005.01424.x

Ord, J. K., \& Getis., A. (2001). Testing for local spatial autocorrelation in the presence of global autocorrelation Journal of Regional Science, 41, 411-432.

President's Malaria Initiative. (2013). Malaria Operational Plan,Rwanda FY (pp. 55). Kigali.

Protopopoff, N., Bortel, W. V., Speybroeck, N., Van Geertruyden, J.-P., Baza, D., \& D’Alessandro, U. (2009).

Ranking malaria risk factors to guide malaria control efforts in African Highlands. PLoS One, 4. 
Smith, M. W., Macklin, M. G., \& Thomas, C. J. (2013). Hydrological and geomorphological controls of malaria transmission. Earth-Science Reviews, 116(0), 109-127. doi: http://dx.doi.org/10.1016/j.earscirev.2012.11.004

Stern, D. I., Gething, P. W., Kabaria, C. W., Temperley, W. H., Noor, A. M., Okiro, E. A., . . Hay, S. I. (2011). Temperature and malaria trends in highland East Africa. PLoS One, 6. doi: 10.1371/journal.pone.0024524

Stratton, L., O'Neill, M. S., Kruk, M. E., \& Bell, M. L. (2008). The persistent problem of malaria: Addressing the fundamental causes of a global killer. Social Science \& Medicine, 67(5), 854-862. doi: http://dx.doi.org/10.1016/j.socscimed.2008.05.013

Stratton, L., O’Neill, M. S., Kruk, M. E., \& Bell, M. L. (2008). The persistent problem of malaria: addressing the fundamental causes of a global killer. Soc Sci Med, 67.

Sutherst, R. W. (2004). Global change and human vulnerability to vector-borne diseases. Clin Microbiol Rev, 17.

Tabachnick, B. G., \& Fidell, L. S. (2001). Using Multivariate Statistics. Bacon: Needham Heights.

van Lishout, M. (2005). Malaria risk scenarios for Kisumu, Kenya: blending qualitative and quantitative information. In W. Takken, P. Martens \& R. J. Bogers (Eds.), Environmental Change and Malaria Risk: Global and Local Implications. Springer, Dordrecht: Wageningem UR Frontis Series.

WHO. (2008). World Malaria Report 2008 (pp. 183). Geneva: World Health Organisation.

Wielgosz, B., Mangheni, M., Tsegai, D., \& Ringler, C. (2012). Malaria and Agriculture. A Global Review of the Literature With a Focus on the Application of Integrated Pest and Vector Management in East Africa and Uganda. IFPRI Discussion Paper(01232), 1-64.

Zayeri, F., Salehi, M., \& Pirhosseini, H. (2011). Geographical mapping and Bayesian spatial modeling of malaria incidence in Sistan and Baluchistan province, Iran. Asian Pacific Journal of Tropical Medicine, 4(12), 985-992. doi: http://dx.doi.org/10.1016/S1995-7645(11)60231-9 